\title{
The Effectiveness of Multimedia-Based Learning on Students' Concept Understanding at Grade 4 Elementary School in Kediri District
}

\author{
Ida Ermiana* \\ Primary Teacher Education Program \\ Universitas Mataram \\ NTB Indonesia \\ ida_ermiana@unram.ac.id
}

\author{
I Nyoman Karma \\ Primary Teacher Education Program \\ Universitas Mataram \\ NTB Indonesia
}

\author{
Lalu Hamdian Affandi \\ Primary Teacher Education Program \\ Universitas Mataram \\ NTB Indonesia
}

\begin{abstract}
This research aims to determine the effect of multimedia-based learning on the students' concept understanding at the fourth-grade of elementary school in Kediri district. This research is quantitative in nature with a quasiexperimental design. The cluster random sampling was used and there were 22 students involved in this research. Repeated Measure ANOVA was used to test the hypotheses with the significance value of 0.05 . The results indicate that multimediabased learning affects the student's understanding concept significantly. It was found that students' understanding concepts was higher when treated with Multimedia-Based Learning than when not treated with Multimedia-Based Learning. There were differences in student learning outcomes indicated by by the increasing of students' understanding scores when the treatment was given.
\end{abstract}

Keywords - multimedia-based learning, understanding concepts

\section{INTRODUCTION}

Understanding the concepts of several materials that are integrated into a theme or sub-theme is a characteristic of the 2013 curriculum that uses a scientific approach. Usually, students memorize concept definitions more quickly than just noticing the relationship between one concept and another. Consequently, the new concept is not integrated in the existing concept, but it stands alone without being related to other concepts. Thus, the new concept cannot be used by students and has no meaning, this is because the concept will be meaningful as it relates to other concepts.

Concepts, laws or principles on integrated subject matter become integrated thematic in which it is not divided into several fields of study. However, in its application there are still several schools that do not use integrated thematic. Thus, this research aims to analyze if multimedia-based learning as an alternative in integrating the whole materials which covers words/sentences, texts, images, or videos that exist in a learning medium can affect students' understanding of concepts. The use of learning media can also be used individually or in groups. Therefore, the researcher wants to find out and prove whether multimedia-based learning influences students' concept understanding at the fourth-grade of elementary school in Kediri District.
The are two research questions formulated in this research, namely: (1) Is there any effect of multimediabased learning on the students' concept understanding at the fourth-grade students of elementary school in Kediri district.; (2) Is there any difference in student learning outcomes when using multimedia-based learning from that when not using it?

\section{LITERATURE REVIEW}

Rossi and Breidle (cited in Wina Sanjaya, 2009: 163) stated that learning covers all tools and materials that can be used to achieve educational goals such as radio, television, books, newspapers, magazines, computers, and so on. According to Rossi, tools such as radio, computers, and television can be categorized as learning media if used in learning processes. According to Reiser and Gagne (Gagne, Briggs and Wager, 1992: 208) ${ }^{3}$, learning media are facilities that are physically used to convey messages in the learning process, consisting of books, audiotapes, training tools, TV programs, and manuals which are combined with others physical facilities. One of the learning media that utilizes the sophistication of technology is multimedia-based learning.

Multimedia-based learning is a learning media with Macromedia Flash software in the form of a tutorial intended for elementary students in the fourth-grade for theme 6 "my future goals" with subtheme "the greatness of my future goals." The material was packed in software to find out students' understanding of concepts.

The concept here is understood as a series of stimuli that have the same characteristics. A concept, as stated by Brunner, Goodnew, and Austin (Sudjana, 2000: 131) consists of elements which covers two things. First psychological review, the concept that contains the same things, arranged and incorporated in an object. Second, the concept has a relation to the components in a process and event.

According to Sudjana (2000: 132$)^{4}$, there are three conditions in learning concepts. The first is the psychological development of students that encourages students' willingness and ability to use concepts. Second, students state, describe, or give meaning to a pattern or series. Third is a condition in which students provide a name for the concept. Understanding the concept here is 
measured from the results of answering questions in multimedia-based learning and teacher's questions during the learning processes.

Thus, concept can be understood as a network of relationships among objects, events, etc., which have fixed features and can be observed. For example, students can recognize objects made of woven bamboo which are round in shape and used to shade and decorate lamps as lampshades. Therefore, whenever a student discovers objects that have the same characteristics of lampshade as stated above, they will immediately recognize that those obeject as lampshades. Students also need technical skills that should be mastered so that those skills can be applied in different or future situations. The process of mastering and applying are considered as learning activities.

\section{RESEARCH METHOD}

This is a quantitative research with quasi-experiment that aims to determine the effect of multimedia-based learning on the concept understanding of the fourth-grade students at the elementary school in Kediri district. The population of this study was 257 students ( 11 classes) of grade IV at elementary schools in the Kediri district. The cluster random sampling technique was used for the purpose of this research was and thus one classroom of the fourth-grade students in SDN 1 Rumak was chosen as the sample which consisted of 22 students. The data were collected by using observation and test on concep understanding. Then the collected data from questionnaire were analyzed quantitatively.

\section{RESULTS AND DISCUSSION}

The kolmogorov-smirnov in SPSS was used to calculate the normality test with a criterion of $(p)$ value 0.05 at the $5 \%$ significance level. The test results are as follows.

\begin{tabular}{|l|r|r|r|r|r|r||}
\hline \multicolumn{8}{|c|}{ Tests of Normality } \\
\hline & \multicolumn{2}{|c|}{ Kolmogorov-Smirnov } & \multicolumn{3}{|c|}{ Shapiro-Wilk } \\
\cline { 2 - 7 } & Statistic & \multicolumn{1}{|c|}{ df } & \multicolumn{1}{|c|}{ Sig. } & Statistic & \multicolumn{1}{c|}{ df } & Sig. \\
\hline Pretest & .184 & 14 & $.200^{\circ}$ & .875 & 14 & .049 \\
Posttest1 & .123 & 14 & $.200^{\circ}$ & .963 & 14 & .770 \\
Posttest2 & .222 & 14 & .060 & .804 & 14 & .006 \\
Posttest3 & .204 & 14 & .120 & .797 & 14 & .005 \\
\hline \multicolumn{7}{|c|}{ a. Lilliefors Significance Correction } \\
*. This is a lower bound of the true significance. \\
\hline
\end{tabular}

Fig. 1. The Results of Normality Test

Test of Homogeneity of Variances

\begin{tabular}{|c|r|r|c|}
\hline $\begin{array}{l}\text { Levene } \\
\text { Statistic }\end{array}$ & df1 & \multicolumn{1}{c|}{$\mathrm{df2}$} & Siq. \\
\hline 1.313 & 3 & 73 & .277 \\
\hline
\end{tabular}

Fig. 2. The results of homogeneity test

Mauchly's Test of Sphericity

\begin{tabular}{|c|c|c|c|c|c|c|c|}
\hline \multirow{2}{*}{$\begin{array}{l}\text { Within } \\
\text { Subjec } \\
\text { ts } \\
\text { Effect }\end{array}$} & \multirow[b]{2}{*}{ Mauchly's w } & \multirow[b]{2}{*}{$\begin{array}{l}\text { Approx. Chi- } \\
\text { Square }\end{array}$} & \multirow[b]{2}{*}{$\mathrm{df}$} & \multirow[b]{2}{*}{ Sig. } & \multicolumn{3}{|c|}{ Epsilon" } \\
\hline & & & & & $\begin{array}{c}\text { Greenhouse- } \\
\text { Geisser }\end{array}$ & Huynh-Feldt & Lower-bound \\
\hline factor1 & .186 & 19.726 & 5 & .001 & 492 & .540 & .333 \\
\hline
\end{tabular}

Fig. 3. The results of Mauchly test

Whereas the data homogeneity test was conducted to find out whether the four students' understanding data gotten from pretest, posttest 1 , posttest 2 , and posttest 3 had the same variance or not. The data is considered homogen if the value of Levene Statistics is higher than 0.05. This means that data about understanding students' concepts are homogeneous.

Based on the Mauchly test results below, it is known that the significance value is 0.001 which is lower than 0.05 . So, the sphericity assumption was not meet. Thus, the conclusion is drawn by using Greenhouse and Geisser correction as an alternative. The significance value is listed as 0.000 which means it is lower than 0.05 , so it can be concluded that there are at least two significantly different mean groups of the data so that $\mathrm{Ha}$ is accepted and $\mathrm{H} 0$ is rejected. This means that multimedia affects the concept understanding of students.

The hypothesis of this research was tested by using Repeated Measure Anova. The test criteria are the significance value (p) is lower than 0.05 at the $5 \%$ significance level. Then there are at least two significantly different mean groups of data. The hypothesis of this research is $\mathrm{H} \_0=\mathrm{x}^{\prime} \_1=\mathrm{x}^{\prime} \_2=\mathrm{x}^{\prime} .33=\mathrm{x}^{\prime} \_4$, while Ha 
$=x^{\prime} \_1 \neq x^{\prime} 2_{0}^{\prime} x^{\prime} 3 \neq x^{\prime} \_4$, or there are at least two significantly different mean groups. Here are the results of repeated measurements of the ANOVA.

The results of the hypothesis test indicate that the data are significantly different which is then proceed with the Post Hoc2 test. The test criteria are if the significance value (p) is lower than 0.05 at the $5 \%$ significance level, the mean of the two samples compared is significantly different.

The post hoc test results, namely the pretest, posttest 1 , posttest 2 , and posttest 3 data are represented in sequence with numbers 1, 2, 3, and 4. From the test results, several points can be formulated as follows: (a) Pretest and posttest 1 data have a significance value of 0.005 which is lower than 0.05 which means that the two data differ significantly; (b) Pretest and posttest 2 data have a significance value of 0.274 which is higher than 0.05 which means that the two data are not significantly different; (c) Pretest and posttest 3 data have a significance value of 0.000 which is lower than 0.05 which means that the two data are significantly different; (d) Posttest 1 and posttest 2 data have a significance value of 0.584 , greater than 0.05 which means that the two data are not significantly different; (e) Posttest 1 and posttest 3 data have a significance value of 0.269 which is higher than 0.05 which means that the two data are not significantly different; (f) Posttest 2 and posttest 3 data have a significance value of 0.025 smaller than 0.05 which means that the two data are significantly different. These data indicate that there are differences in the scores of students when given multimedia-based learning treatment and when without this treatment. Effect sizes are displayed to better know the effect size or effect size of the instructional media on the students' concept understanding. In this study the effect size value can be seen using partial eta squared which can be generated by the SPSS program.

Tests of Within-Subjects Effects

\begin{tabular}{|c|c|c|c|c|c|c|c|}
\hline Source & & $\begin{array}{l}\text { Type III Sum } \\
\text { of Squares }\end{array}$ & df & Mean Square & $\mathrm{F}$ & Sig. & $\begin{array}{l}\text { Partial Eta } \\
\text { Squared }\end{array}$ \\
\hline \multirow[t]{4}{*}{ factor1 } & Sphericity Assumed & 3023.214 & 3 & 1007.738 & 8.315 & .000 & .390 \\
\hline & Greenhouse-Geisser & 3023.214 & 1.475 & 2049.039 & 8.315 & .005 & .390 \\
\hline & Huynh-Feldt & 3023.214 & 1.619 & 1867.559 & 8.315 & .004 & .390 \\
\hline & Lower-bound & 3023.214 & 1.000 & 3023.214 & 8.315 & .013 & .390 \\
\hline \multirow[t]{4}{*}{ Error(factor1) } & Sphericity Assumed & 4726.786 & 39 & 121.200 & & & \\
\hline & Greenhouse-Geisser & 4726.786 & 19.181 & 246.436 & & & \\
\hline & Huynh-Feldt & 4726.786 & 21.044 & 224.609 & & & \\
\hline & Lower-bound & 4726.786 & 13.000 & 363.599 & & & \\
\hline
\end{tabular}

Fig. 4. The Result of Hypothesis test by using Repeated Measure Anova

\section{Post Hoc}

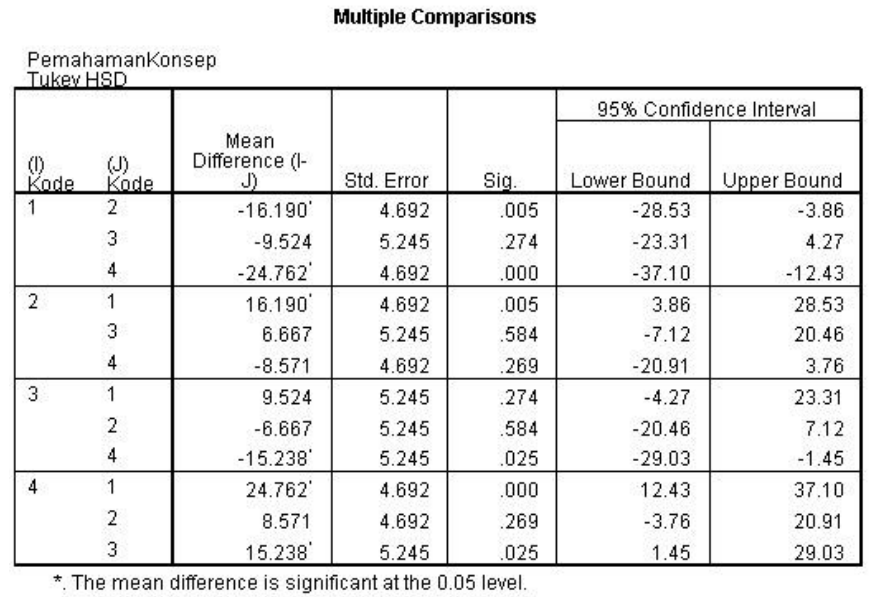

Fig. 5. The Results of Post Hoc Test

Tests of Within-Subjects Effects

\begin{tabular}{|c|c|c|c|c|c|c|c|}
\hline Source & & $\begin{array}{l}\text { Type III Sum } \\
\text { of Squares }\end{array}$ & df & Mean Square & $\mathrm{F}$ & Siq. & $\begin{array}{c}\text { Partial Eta } \\
\text { Squared }\end{array}$ \\
\hline \multirow[t]{4}{*}{ factor1 } & Sphericity Assumed & 3023.214 & 3 & 1007.738 & 8.315 & .000 & .390 \\
\hline & Greenhouse-Geisser & 3023.214 & 1.475 & 2049.039 & 8.315 & .005 & .390 \\
\hline & Huynh-Feldt & 3023.214 & 1.619 & 1867.559 & 8.315 & .004 & .390 \\
\hline & Lower-bound & 3023.214 & 1.000 & 3023.214 & 8.315 & .013 & .390 \\
\hline \multirow[t]{4}{*}{ Error(factor1) } & Sphericity Assumed & 4726.786 & 39 & 121.200 & & & \\
\hline & Greenhouse-Geisser & 4726.786 & 19.181 & 246.436 & & & \\
\hline & Huynh-Feldt & 4726.786 & 21.044 & 224.609 & & & \\
\hline & Lower-bound & 4726.786 & 13.000 & 363.599 & & & \\
\hline
\end{tabular}

Fig. 6. The Results of Effect Size with Partial Eta Squared 
The partial eta squared value generated from the measurement data of student learning outcomes is 0.39 which is categorized into low category. The number 0.39 indicated by partial eta squared means that students' concept understanding variables are influenced by $39 \%$ of multimedia variables, excluding the influence of other external variables.

The comparison of the mean for each treatment given shows the difference when using multimedia-based learning with those when not using it. This shows that multimedia is one of the factors influencing the concept understanding of grade IV students at SDN 1 Rumak. The mean pretest value was 43.33. Posttest I with a score of 59.52. Posttest II scores dropped to 56.92 and rose again in posttest III to 71.5. This indicates that students' concept understanding increases when a multimedia-based learning treatment is given and decreases when it is not.

Based on the results of hypothesis testing, it can be concluded that multimedia-based learning has a significant effect on students' concept understanding. This is proved by the increasing scores of students in concept understanding when given treatment. When the teacher asked questions such as 'what are your goals after reading the poem about future goals?' There were students who answered 'teachers, nurses, police, judges, merchant' and others. Students were also able to differentiate places and assignments for each of the jobs they mentioned.

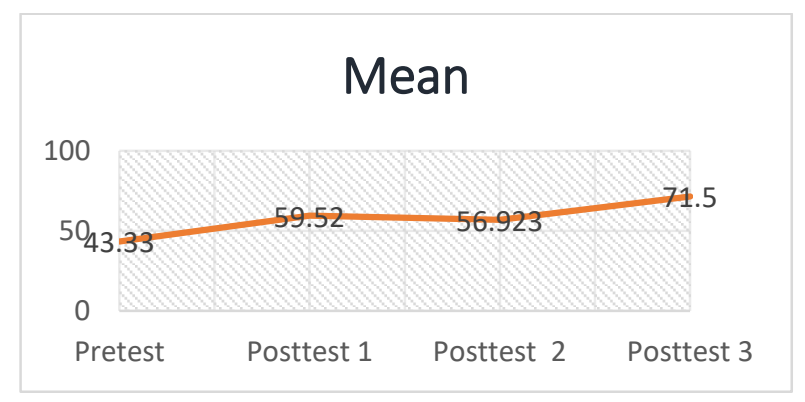

Fig. 7. Comparison Graph of Students' Concepts Understanding

\section{CONCLUSION}

The result of the hypothesis test indicates the significance value with the value 0.000 , which is smaller than 0.05 , thus $\mathrm{Ha}$ is accepted and $\mathrm{HO}$ is rejected. This means that there is a significant effect of multimedia-based learning on the concept understanding of fourth-grade students at elementary school in Kediri District. The comparison of the mean values for each treatment given shows the difference when using multimedia-based learning from when it is not. Students' scores of concept understanding increased when given treatment and decreased when it was not, and rose again when treatment was given.

\section{REFERENCES}

[1] Dennis, Howitt \& Duncan Cramer. 2011. Introduction SPSS Statistics in Psychology For Version 19 and earlier Fifth edition. Italy. Rotolito Lombarda.

[2] Hand,D.J \& Taylor, C.C. 1987. Multivariate Analysis of Variance and Repeated Measures A Practical Approach For Bevavioural Scientists. London. Chapman and Hall.

[3] Gagne, R.M., Briggs, L.J., \& Wager, W.W. 1992. Principles Instructional Design (4th ed). Orlando: Harcourt Brace Jovanovich College

[4] Sudjana, S.D.2000. Strategi Pembelajaran. Bandung: Falah Production.

[5] Wina Sanjaya. 2009. Strategi Pembelajaran Berorientasi Standar Proses Pendidikan. Jakarta: Kencana. 